Informatio: Journal of Library and Information Science Vol. 1(1), 67-82, Januari 2021

ISSN 2775-0043 (Online)

\title{
Komunikasi instruksional volunteer pengajar Komunitas 1000 Guru Bandung pada aktivitas literasi TNT \#18
}

\author{
Annisa Yuniar ${ }^{*}$, Rohanda ${ }^{b}$, Fitri Perdana ${ }^{c}$ \\ abc Fakultas Ilmu Komunikasi Universitas Padjadjaran Bandung
}

\begin{abstract}
Abstrak
Penelitian ini membahas mengenai aktivitas literasi Travelling and Teaching (TNT) \#18 yang dilakukan oleh sukarelawan pengajar Komunitas 1000 Guru Bandung. Tujuan dari penelitian ini adalah untuk mengetahui bagaimana aktivitas literasi yang dilak ukan oleh sukarelawan pengajar Komunitas 1000 Guru Bandung. Metode penelitian yang digunakan ialah metode kualitatif dengan pendekatan studi kasus. Teknik pengumpulan data dilakukan melalui observasi partisipatif, wawancara, dokumentasi dan studi pustaka. Hasil dari penelitian ini menunjukkan bahwa proses komunikasi instruksional yang dilakukan oleh sukarelawan pengajar Komunitas 1000 Guru Bandung pada saat kegiatan TNT \#18 dimulai dari : 1) Spesifikasi isi dan tujuan komunikasi instruksional mengenai materi dan aktivitas pembelajaran yang terdapat atau tertera di dalam booklet TNT \#18; 2) Penaksiran Perilaku Mula yakni di dalam kegiatan technical meeting untuk menginformasikan mengenai kemampuan siswa (sasaran); 3) Penetapan Strategi Instruksional yang dibagi menjadi 2, yakni : Pertama, Strategi ekspositori (pencarian materi atau bahan ajar melalui buku pelajaran dan internet) dan strategi inkuiri (pemilihan metode fun teaching dan media komunikasi instruksional); 4) Organisasi satuan-satuan Instruksional (pembagian materi, teknis penggunaan media instruksional dan alur pemaparan materi dan simulasi); 5) Umpan balik : review pembelajaran dan 6) Evaluasi. Hambatan yang terjadi pada saat kegiatan TNT \#18 tidak ada karena dari awal tujuan pembelajarannya sudah direncanakan secara matang sehingga pada proses pembelajarannya hambatanhambatan tersebut dapat diantisipasi. Kesimpulan dalam penelitian ini ialah bahwa komponen atau proses tambahan pada proses komunikasi instruksional di akhir sesudah melakukan review ialah evaluasi mengenai proses komunikasi instruksional secara keseluruhan dan juga hambatan. Tetapi hambatan ini bisa dieliminir atau bisa dihindari karena proses komunikasi instruksional ini sudah direncanakan sedemikian rupa sebelumnya. Untuk penelitian selanjutnya, disarankan untuk melakukan penelitian lebih mendalam mengenai sukarelawan pengajar Komunitas 1000 Guru Bandung. Diharapkan dapat terciptanya inovasi dalam berbagai kegiatan sukarelawan pengajar Komunitas 1000 Guru Bandung demi mewujudkan sistem pembelajaran yang lebih baik lagi.
\end{abstract}

Kata kunci: Komunikasi instruksional; Proses komunikasi instruksional; Komunitas 1000 Guru Bandung; Pengajar; Sukarelawan

Korespondensi: Annisa Yuniar, Fakultas Ilmu Komunikasi, Universitas Padjadjaran, Jl. Ir. Soekarno Km. 21, Jatinangor, Sumedang, Jawa Barat 45363, Indonesia

Email: annisa16008@mail.unpad.ac.id

http://jurnal.unpad.ac.id/informatio

DOI: https://doi.org/10.24198/inf.v1i1.31538

Received: Januari 2021; Accepted: Januari 2021; Published: Januari 2021

(C) Informatio 2021. This is an open access article under the CC BY-SA license 


\title{
Instructional communication of Teaching Volunteers Komunitas 1000 Guru Bandung at literacy activity of TNT \#18
}

\begin{abstract}
This study discusses the literacy activity of Travelling and Teaching (TNT) \# 18 carried out by teaching volunteers of the 1000 Guru Bandung Community. The purpose of this study is to find out ho literacy activity is carried out by volunteers 1000 Guru Bandung Community. This research used qualitative method with case study approach. Data in this study were obtained through participatory observation, interviews, documentation and literature review. The results of this study indicate that the instructional communication process carried out by the teaching volunteers of 1000 Guru Bandung community during TNT \#18 program includes: 1) Content specifications and instructional communication objectives regarding learning materials and activities contained or listed in the TNT \# 18 booklet; 2) Initial Behavior Assessment in technical meeting to inform about the ability of students (target); 3) Determination of Instructional Strategies which are dichotomized into: Expository Strategies (searching for teaching materials through textbooks as well as the internet) and inquiry strategies (selection of fun teaching methods and instructional communication media); 4) Organization of Instructional units (distribution of material, techniques for using instructional media and flow of material presentation, simulation); 5) Feedback: learning review; and 6) Evaluation. There were no significant obstacles that occurred during TNT \# 18 program since learning objectives had been so carefully planned from the start that any potential obstacles could be anticipated. The conclusion of this research is that an additional component or process in the instructional communication process at the end after conducting a review is an evaluation of the instructional communication process as a whole and also barriers. But these obstacles can be eliminated or can be avoided because this instructional communication process has been planned in such a way in advance. For further research, it is advisable to conduct more in-depth research on teaching volunteers of the 1000 Guru Bandung Community. It is expected that innovation can be created in the various volunteer teaching activities of the 1000 Guru Bandung Community in order to create a better learning system.
\end{abstract}

Keywords: Instructional communication; Instructional communication process; 1000 Guru Bandung Community; Instructor; Volunteer

\section{PENDAHULUAN}

Komunitas 1000 Guru Bandung hadir sebagai komunitas yang berfokus pada semangat pendidikan anak-anak di pelosok negeri terutama di Jawa Barat. Berdasarkan tagline Komunitas 1000 Guru Bandung "Berawal dari hati, Berbagi untuk anak negeri”, Komunitas 1000 Guru Bandung berdiri karena memiliki tujuan untuk ikut andil dalam kemajuan pendidikan anak-anak Indonesia. Secara garis besar, Komunitas 1000 Guru Bandung memiliki 5 (lima) kegiatan atau aksi, diantaranya : (1) Beasiswa Guru Pedalaman; (2) Travelling and Teaching (TNT); (3) Teaching and Giving (TNG); (4) Moral Campaign dan (5) Smart Centre. Penulis lebih tertarik untuk melakukan penelitian di dalam kegiatan Travelling and Teaching (TNT) dengan lebih menitikberatkan penelitian ini pada kegiatan pengajarannya saja. Hal ini dikarenakan pada bagian pengajaran, sukarelawan pengajar memberikan pembelajaran yang kreatif dan inovatif, tidak hanya mengajar seperti 
biasanya. Sukarelawan pengajar mengajak siswa untuk aktif di kelas dengan menggunakan berbagai macam media dan metode yang berbeda-beda.

Komunitas 1000 Guru Bandung hadir dalam kegiatan Travelling and Teaching (TNT) untuk memberikan pembelajaran yang kreatif, aktif dan inovatif. Komunitas nirlaba ini berdiri karena adanya sebuah kepedulian akan pendidikan anak-anak terutama Sekolah Dasar (SD) atau Madrasah Ibtidaiah (MI) di pelosok daerah Jawa Barat. Sebenarnya sudah banyak komunitas peduli pendidikan anak-anak pedalaman lainnya di Jawa Barat tetapi Komunitas 1000 Guru Bandung ini memiliki keunikan lain yakni mereka melakukan pendataan dan survei terlebih dahulu ke sekolah di Pelosok Jawa Barat yang memang berhak diadakan kegiatan Travelling and Teaching (TNT). Pengelola Komunitas 1000 Guru Bandung melakukan penjaringan sukarelawan pengajar untuk ikut langsung dalam kegiatan Travelling and Teaching (TNT). Pada saat memberikan pembelajaran, sukarelawan pengajar Komunitas 1000 Guru Bandung terlibat langsung dalam penyusunan tujuan komunikasi instruksional. Sukarelawan pengajar menggunakan berbagai metode pembelajaran serta media instruksional beragam yang tentu penggunaan atau perancangannya berdasarkan hasil survei yang dilakukan sebelumnya dan disesuaikan dengan keadaan di lapangan.

Kegiatan Travelling and Teaching (TNT) menyasar anak-anak muda usia 19 - 35 tahun sebagai sukarelawan khususnya yang menyukai travelling ke pedalaman Jawa Barat. Selain untuk menjelajahi lokasi wisata, kegiatan ini sekaligus mengajak sukarelawan untuk terlibat mengajar adik-adik Sekolah Dasar (SD) atau Madrasah Ibtidaiah (MI) di daerah sekitar lokasi travelling. Kegiatan ini biasanya berlangsung 2 - 3 (dua sampai tiga) bulan sekali dalam durasi waktu 3 (tiga) hari 2 (dua) malam dan biasanya diadakan pada saat weekend (akhir pekan). Hingga pada saat ini setidaknya sudah kurang lebih 300 sukarelawan atau sukarelawan pengajar yang ikut dalam kegiatan Travelling and Teaching (TNT) untuk memberikan pembelajaran kepada lebih dari 1228 anak dengan 22 Sekolah Dasar (SD) yang sudah dikunjungi semenjak komunitas ini berdiri. Komunitas 1000 Guru Bandung berharap bahwa dengan adanya kegiatan ini motivasi belajar anak-anak yang dikunjungi dapat meraih cita-citanya dan tidak putus sekolah.

Sukarelawan, menurut Kamus Besar Bahasa Indonesia (KBBI) berarti orang yang melakukan sesuatu dengan sukarela, tidak diwajibkan atau dipaksakan (Balitbang Kemendikbud, 2020). Sukarelawan juga adalah orang-orang yang tidak memiliki kewajiban menolong suatu pihak tetapi memiliki dorongan untuk berkontribusi nyata dalam suatu kegiatan dan berkomitmen untuk terlibat dalam kegiatan yang membutuhkan kerelaan untuk mengorbankan waktu, tenaga, pikiran, serta materi untuk diberikan 
kepada orang lain. Selain itu, kegiatan yang dilakukan sukarelawan bersifat sukarela untuk menolong orang lain tanpa adanya harapan akan imbalan eksternal (Rizkiawati, 2017).

Pada saat kegiatan Travelling and Teaching (TNT) \#18 berlangsung para sukarelawan pengajar Komunitas 1000 Guru Bandung merelakan waktunya, tenaga, pikiran serta materi untuk mengajar anak-anak di SDN Cikidang. Para sukarelawan pengajar menggunakan cara mengajar yang sangat kreatif yakni fun teaching. Pada kegiatan tersebut bukan hanya Tim Komunitas 1000 Guru Bandung saja yang merencanakan pembelajarannya tetapi para sukarelawan pengajar juga ikut dalam menyusun bahan ajarnya. Fun teaching terdiri dari 2 (dua) kata, yakni fun yang berarti menyenangkan dan teaching yang berarti pengajaran, maka fun teaching berarti menciptakan suasana belajar yang hura-hura. Menyenangkan dan hura-hura yang dimaksud disini ialah membangkitkan minat untuk belajar, , membuat sasaran nyaman, aman dan tenang ketika mengaktualisasi kemampuan dirinya, merangsang keterlibatan penuh serta menciptakan pemahaman atas materi yang dipelajari.

Penyajian metode belajar fun teaching ini bervariatif agar sasaran tidak jenuh dalam belajar, sasaran tidak merasa terbebani oleh materi, perasaan senang dapat hadir dengan tujuan materi dapat diserap dengan baik dan mudah. Dave Meiler dalam Muhaimin (2011) menjelaskan bahwa ciri-ciri suasana belajar yang menyenangkan, antara lain : 1) Rileks; 2) Bebas dari tekanan; 3) Aman; 4) Menarik; 5) Bangkitnya minat belajar; 6) Adanya keterlibatan penuh; 7) Perhatian peserta didik tercurah; 8) Lingkungan belajar yang menarik (misalnya keadaan kelas terang, pengaturan tempat duduk leluasa untuk sasaran bergerak); 9) Bersemangat; 10) Perasaan gembira dan 10) Konsentrasi tinggi. Inti dari atau asas utama dari fun teaching sendiri ialah menjadikan belajar semakin asyik, karena belajar tidak selalu berurusan dengan hal-hal yang bersifat serius. Dengan bermain sambil belajar seperti contohnya olahraga, bercanda atau dalam bentuk senang-senang lainnya sasaran akan mendapatkan dampak yang lebih besar salah satunya kreativitas yang biasanya aktivitas ini dianggap remeh.

Fun teaching akan membuat sasaran lebih berani mencoba dan berbuat, berani bertanya serta berani mengemukakan pendapat. Beberapa contoh metode dan media yang digunakan pada saat dilakukannya fun teaching, antara lain : bermain, bercerita, bernyanyi, humor dan tebak-tebakan. Jenis-jenis media komunikasi instruksional sebenarnya cukup banyak dan bervariasi, seperti diurutkan berdasarkan asal pelahirannya, sebagai berikut : objek nyata dan model, teks cetakan (buku, handouts, worksheets), visual cetak (gambar, foto, lukisan, bagan, grafik dan lain-lain), interactive whiteboards, overhead transparencies, slides and filmstrips, audio (tape, disc, voice), video and film 
(tape, disc), television (live), computer software, web offline, intranet dan internet (Yusup, 2010).

Selain itu, pada saat memberikan pembelajaran sukarelawan pengajar Komunitas 1000 Guru Bandung terlibat langsung dalam penyusunan tujuan komunikasi instruksional yang akhirnya menggunakan berbagai metode pembelajaran serta media instruksional beragam. Trik ini juga dirancang berdasarkan hasil survei yang dilakukan sebelumnya, disesuaikan dengan keadaan di lapangan dan sasaran, seperti contohnya : apakah anakanak sudah bisa membaca, menulis dan berhitung. Oleh karena itu, sukarelawan pengajar memiliki peran penting untuk menerapkan komunikasi instruksional yang baik kepada anak-anak untuk meningkatkan motivasi dan semangat mereka dalam belajar. Anak-anak akan tertarik dan berpartisipasi aktif ketika pembelajaran berlangsung.

Komunikasi instruksional itu berarti komunikasi di dalam bidang instruksional yang membahas apa dan bagaimana komunikasi instruksional serta tujuan-tujuan yang mungkin bisa dicapai dalam sistem (komunikasi) instruksional. Komunikasi dalam sistem instruksional ini kedudukannya dikembalikan lagi pada fungsi asalnya, yakni sebagai alat untuk mengubah perilaku sasaran (edukatif). Proses komunikasi yang diciptakannya secara wajar, akrab dan terbuka dengan ditunjang oleh faktor pendukung lainnya baik sebagai sarana maupun fasilitas lainnya dengan tujuan supaya mempunyai efek perubahan perilaku pada pihak sasaran. Instruktur dan sasaran melakukan interaksi psikologis yang nantinya diharapkan bisa berdampak pada berubahnya pengetahuan, sikap dan keterampilan di pihak sasaran. Proses interaksi psikologis ini berlangsung paling tidak antara dua orang atau lebih dengan cara berkomunikasi. Proses ini terjadi ketika instruktur berupaya membantu terjadinya proses perubahan tadi atau proses belajar di pihak sasaran yang prosesnya disengaja dan diupayakan terjadi. Teknik atau alat untuk melaksanakan proses ini ialah komunikasi instruksional. Sasaran dari komunikasi instruksional yang direncanakan ini ialah sekelompok orang, yakni dari sukarelawan pengajar Komunitas 1000 Guru Bandung kepada Siswa SDN Cikidang.

Terjadinya komunikasi tersebut memang belum menjadi proses instruksional karena yang terakhir ini prosesnya sudah mulai ke ranah teknis dan juga bertujuan, bahkan bisa saja terkontrol sebab pengadaannya diupayakan atau disengaja. Akan tetapi sebaliknya, kegiatan instruksional merupakan proses komunikasi atau setidaknya terdapat peristiwa komunikasi yang sedang berlangsung didalamnya. Apabila proses komunikasi ini bisa diarahkan sesuai dengan tujuan-tujuan instruksional yang ditargetkan oleh instruktur, maka proses belajar pun diharapkan bisa terjadi di pihak sasaran. Hal ini sejalan dengan proses belajar yang berciri menetap dan terus-menerus. Hurt, Scott dan 
Croscey menjelaskan bahwa proses instruksional sebenarnya bisa dibagi ke dalam seperangkat langkah berangkaian, terdiri dari :

1. Spesifikasi Isi dan Tujuan Instruksional, variabel-variabel komunikasinya ialah penambahan informasi dan penafsiran atau pembacaan sandi;

2. Penaksiran Perilaku Mula (Assessment of Entering Behavior), variabel komunikasinya ialah faktor manusia, umpan balik dan juga penyandian;

3. Penetapan Strategi Instruksional, variabel komunikasinya ialah penggunaan saluran seperti strategi apa yang akan digunakan oleh instruktur dalam suatu kegiatan instruksional yang banyak ditentukan oleh situasi dan kondisi medan namun tetap penetapannya bergantung pada instruktur yang akan bertugas nanti. Pertama adalah strategi ekspositori yang berkaitan dengan pemaparan, penjelasan atau penguraian yang bisa didukung dengan berbagai macam sumber informasi pendukung. Kedua adalah strategi inkuiri yang bisa dilakukan dengan bantuan alat-alat dan sarana tertentu sebagai percobaan dengan tujuan untuk menemukan suatu kesimpulan berdasarkan hasil percobaan;

4. Organisasi Satuan-satuan Instruksional, variabel komunikasinya ialah pesan, penyandian dan pengertian sandi

5. Umpan Balik, mempunyai arti yang sangat penting dalam setiap proses instruksional, karena melalui umpan balik inilah kegiatan instruksional bisa dinilai berhasil ataupun sebaliknya (Yusup, 2010).

Maka, berdasarkan penjelasan di atas, tujuan dari penelitian ini adalah untuk mengetahui proses komunikasi instruksional pada aktivitas literasi yang dilakukan oleh sukarelawan pengajar Komunitas 1000 Guru Bandung kepada siswa SDN Cikidang pada saat kegiatan Travelling and Teaching (TNT) \#18. Pada penelitian ini, penulis menjelaskan mengenai aktivitas literasi yang dilakukan oleh sukarelawan pengajar Komunitas 1000 Guru Bandung pada kegiatan Travelling and Teaching (TNT) \#18.

\section{METODE PENELITIAN}

Jenis penelitian yang digunakan dalam penelitian ini adalah metode kualitatif dengan pendekatan studi kasus, teknik pengumpulan data yang dihasilkan bersifat deskriptif, bergerak dari isu, tidak menguji teori tetapi menemukan teori. Penelitian metode kualitatif dengan pendekatan studi kasus akan berupaya menelaah sebanyak mungkin data mengenai subjek yang diteliti dengan menggunakan berbagai metode pengumpulan data, sepertiwawancara, observasi atau pengamatan langsung, dokumentasi dan studi pustaka (Moleong, 2012). 
Subjek dan objek dalam penelitian ini sukarelawan pengajar Travelling and Teaching (TNT) \#18 yang akan menjadi informan utama (key informan). Pemilihan sampel diambil dari dua orang di setiap kelasnya, yang terdiri dari satu sukarelawan pengajar dan satu orang pembimbing. Objek penelitian atau aspek yang menjadi titik perhatian atau unit analisis ialah tahapan atau proses komunikasi instruksional yang dilakukan oleh sukarelawan pengajar Travelling and Teaching (TNT) \#18 Komunitas 1000 Guru Bandung. Analisis data dilakukan dengan langkah-langkah yang dikemukakan oleh Miles dan Huberman, yakni Reduksi Data, Penyajian Data (Data Display) dan Conclusion Drawing / Verification (Sugiyono, 2012).

Teknik keabsahan data yang digunakan oleh penulis ialah triangulasi sumber di mana penulis mendapatkan data dari sumber yang berbeda-beda dengan teknik yang sama, yakni dengan cara menanyakan kebenaran data dari yang penulis peroleh dari informan satu ke informan lainnya dan mengecek hasil analisis tersebut kepada triangulator. Penelitian ini dilakukan pada saat penulis mengikuti kegiatan Travelling and Teaching (TNT) \#18 yang diadakan oleh Komunitas 1000 Guru Bandung. Kegiatan ini berlokasi di Sekolah Dasar Negeri Cikidang, Kampung Cikidang, Desa Sukaresmi, Kecamatan Rancabali, Kabupaten Bandung. Penulis melakukan penelitian ini dalam kurun waktu tiga bulan, yang dimulai dari bulan Juni sampai dengan bulan September 2019.

\section{HASIL DAN PEMBAHASAN}

Pengamatan yang dilakukan oleh penulis dimulai dari penulis mengikuti perekrutan sukarelawan pengajar yang diadakan oleh Komunitas 1000 Guru Bandung dan setelah itu penulis mengikuti beberapa rangkaian acara yang diadakan sebelum kegiatan Travelling and Teaching (TNT) \#18 berlangsung. Hasil observasi partisipatif yang dilakukan penulis selama berada di lapangan (tempat penelitian) yakni Sekolah Dasar Negeri Cikidang yang bertempat di tengah perkebunan teh, penulis ditempatkan untuk mengajar di kelas 2 (dua) dan tidak diperbolehkan untuk mengambil dokumentasi berupa foto ataupun video selama kegiatan Teaching berlangsung, sehingga penulis dan sukarelawan pengajar lainnya akan diberikan link Google Drive untuk mendapatkan foto-foto atau video yang diambil selama kegiatan Travelling and Teaching (TNT) \#18.

Di dalam proses komunikasi instruksional pada kegiatan Travelling and Teaching (TNT) \#18 ini terdapat 3 (tiga) komponen penting, diantaranya:

1. Instruktur (Sukarelawan pengajar Komunitas 1000 Guru Bandung)

2. Sasaran (Siswa Sekolah Dasar Negeri Cikidang) 
3. Saluran (Metode atau Media pembelajaran).

Ketiga komponen ini sangat berkaitan erat dengan proses komunikasi instruksional. Sukarelawan pengajar Komunitas 1000 Guru Bandung akan memberikan pembelajaran kepada siswa Sekolah Dasar Negeri Cikidang dimulai dari kelas 1 (satu) hingga kelas 6 (enam) dengan menggunakan media pembelajaran yang sudah disiapkan sebelumnya. Proses komunikasi instruksional yang dilakukan oleh sukarelawan pengajar Komunitas 1000 Guru Bandung pada saat kegiatan Travelling and Teaching (TNT) \#18 ialah dimulai dari tahap persiapan yakni survei, padahal sebetulnya tahapan dari proses komunikasi instruksional yang dikemukakan oleh Hurt, Scott dan Croscey yang dimulai dari spesifikasi isi dan tujuan instruksional, tetapi Komunitas 1000 Guru Bandung melakukan survei terlebih dahulu lalu dilanjutkan dengan menentukan tujuan dari instruksional yang akan dilakukan nanti ketika berada di lokasi Travelling and Teaching (TNT) sesudah melakukan survei.

Tahapan-tahapan ini akan penulis jelaskan dan penulis kaitkan dengan tahapan proses komunikasi instruksional yang dikemukakan oleh Hurt, Scott dan Croscey pada saat kegiatan Teaching yang dilakukan oleh Sukarelawan pengajar Komunitas 1000 Guru Bandung, ialah diawali dari pertama yakni Spesifikasi Isi dan Tujuan Instruksional. Hurt, Scott dan Croscey dalam (Yusup, 2010) menyebutkan bahwa variabel komunikasinya ialah penambahan informasi, penyajian dan penafsiran informasi yang akan disampaikan oleh instruktur kepada sasarannya agar sasaran tidak salah memola tujuan yang ingin disampaikan oleh instruktur. Cara yang dapat dipilih untuk menghindari masalah tersebut adalah mengkhususkan isi dan tujuan-tujuan instruksionalnya yang ditulis dalam kerangka persiapan instruktur sebelum melaksanakan tugasnya dilapangan.

Komunitas 1000 Guru Bandung menetapkan materi atau bahan ajar (tujuan instruksional) yang nanti akan diberikan kepada siswa SDN Cikidang yang penjelasan mengenai materi atau bahan ajar ini dituangkan ke dalam buku panduan atau Booklet TNT \#18. Booklet TNT \#18 ini pun menjadi kerangka persiapan bagi sukarelawan pengajar sebelum turun ke lapangan untuk melaksanakan kegiatan pengajaran di SDN Cikidang. Komunitas 1000 Guru Bandung merujuk pada kurikulum yang mereka dapatkan di Internet maupun anggota yang berprofesi sebagai Guru di dalam tim inti dalam pemilihan materi atau bahan ajar. Setelah mendapatkan rujukan materi atau bahan ajar dari kurikulum, Tim Acara dari Kegiatan Travelling and Teaching (TNT) \#18 akan melakukan ideasi atau tukar ide dengan tim inti komunitas 1000 Guru Bandung untuk menentukan 6 (enam) topik atau materi yang akan diajarkan kepada Siswa SDN Cikidang sesuai dengan tingkatan kelas dari mulai kelas 1 (satu) sampai dengan kelas 6 (enam) yang penjelasan 
materi untuk setiap kelasnya dicantumkan di dalam lesson plan booklet TNT \#18, antara lain :

1. Materi, mencakup point-point apa saja yang ingin disampaikan

2. Aktivitas, mencakup kegiatan apa saja yang perlu dilakukan ketika pembelajaran

3. Penanaman nilai, mencakup sifat apa saja yang harus ditanamkan kepada pihak sasaran.

Kedua, perilaku mula. Variabel komunikasinya ialah faktor manusia dan umpan balik dari pihak sasaran. Hurt, Scott dan Croscey dalam Yusup (2010) menjelaskan bahwa sebelum pelaksanaan kegiatan instruksional instruktur mencoba memahami situasi dan kondisi sasaran, termasuk juga kemampuan awal yang telah dimiliki oleh pihak sasaran. Maka dalam tahap ini berkaitan dengan tahap pertama di mana ketika Komunitas 1000 Guru Bandung yang sudah melakukan survei ke lokasi sasaran (SDN Cikidang) mengolah hasil survei tersebut ke dalam Booklet TNT \#18 dan juga menjelaskan kondisi sasaran pada saat technical meeting. Hal-hal yang disampaikan ketika technical meeting (Techmeet) terkait dengan kondisi sasaran tersebut, antara lain lokasi dan akses menuju sekolah, kondisi infrastruktur sekolah dan jumlah murid secara keseluruhan dan per setiap kelas dan 4) kondisi murid (kemampuan awal seperti baca, tulis, hitung). Alasan Tim Komunitas 1000 Guru Bandung memberikan pemberitahuan mengenai hal-hal di atas ialah agar sukarelawan pengajar lebih mempersiapkan diri sebelum turun ke lapangan dan perencanaan mengenai proses pembelajaran yang akan dilakukan nanti bisa berjalan lancar.

Ketiga, penetapan strategi instruksional. Variabel komunikasinya penggunaan saluran, meliputi strategi ekspositori dan strategi inkuiri seperti yang dikemukakan oleh Hurt, Scott dan Croscey. Strategi ekspositori yang berkenaan dengan pemaparan atau penjelasan yang dilakukan oleh sukarelawan pengajar. Mereka mencari materi-materi atau bahan ajar terkait dari buku cetak pelajaran sekolah dan juga internet. Strategi inkuiri yang berkenaan dengan bantuan alat-alat tertentu untuk pelaksanaannya sendiri disesuaikan dengan isi dan tujuan yang sudah ditetapkan sebelumnya. Sukarelawan pengajar melakukan pemilihan metode pembelajaran, cara dan media komunikasi instruksional.

Setelah dilaksanakannya technical meeting atau Techmeet yang bertujuan untuk menginformasikan mengenai kondisi atau situasi baik itu kondisi lingkungan dalam sekolah ataupun siswa SDN Cikidang dan sudah diberikan buku panduan berupa Booklet TNT \#18 yang didalamnya terdapat lesson plan atau materi yang perlu disampaikan kepada siswa SDN Cikidang. Tahapan selanjutnya ialah penentuan metode dan media pembelajaran yang akan digunakan nanti pada saat pemberian materi. Sukarelawan 
pengajar diberikan waktu untuk berdiskusi ataupun menentukan metode dan media tersebut bersama dengan pendamping kelas dan juga anggota sukarelawan pengajar lain yang sudah dibagi menjadi ke dalam 6 (enam) kelas pada saat technical meeting di dalam grup Whatsapp.

Metode Pembelajaran fun teaching menjadi metode yang dipilih oleh sukarelawan pengajar karena metode pembelajaran ini tidak kaku (interaktif). Proses penyampaian materinya dilakukan secara menyenangkan menggunakan berbagai media instruksional yang menarik dan kreatif yang tentunya dapat diterima oleh siswa agar siswa lebih mudah mengingat dan juga mengerti mengenai pelajaran yang disampaikan. Hal tersebut selaras dengan metode pembelajaran fun teaching yang diutarakan oleh Dave Meiler dalam Muhaimin (2011) yang mengatakan bahwa ciri-ciri suasana belajar yang menyenangkan ialah rileks, bebas dari tekanan, menarik, adanya keterlibatan penuh dari pihak sasaran, bersemangat, perasaan gembira yang didapatkan oleh kedua belah pihak dalam pembelajaran, penyajian materi yang bervariatif tetapi tetap materi dapat diserap dengan baik dan mudah oleh pihak sasaran.

Metode fun teaching ini akan membuat siswa menjadi lebih aktif dalam mengikuti pembelajaran yang dilakukan, berani mencoba, berani bertanya dan juga berani mengungkapkan. Adapun beberapa contoh dari pembelajaran fun teaching yang digunakan oleh sukarelawan pengajar untuk membuat suasana kelas menjadi asyik dan menyenangkan, antara lainbernyanyi, menari, bercerita, games, memberikan hadiah/rewards, ice breaking dan tebak-tebakan.



Gambar 1. Metode Fun Teaching: Menyanyi dan Menari Sumber: Dokumentasi 1000 Guru Bandung (2019)

Yusup (2010) mengatakan bahwa seorang instruktur harus menentukan dan menggunakan media instruksional untuk menyampaikan gagasannya agar lebih mudah diterima oleh pihak sasaran. Maka dalam hal pemilihan media komunikasi instruksional 
yang digunakan, sukarelawan pengajar tidak hanya menggunakan tulisan, lalu didengarkan dan dihafalkan oleh siswa. Media komunikasi instruksional yang digunakan oleh sukarelawan pengajar adalah media yang dibuat oleh tim sukarelawan pengajar itu sendiri dengan biaya yang relatif murah. Media ini memungkinkan terjadinya banyak interaksi antara sukarelawan pengajar dengan siswa dan membantu dalam hal penyampaian materi yang diberikan oleh sukarelawan pengajar kepada siswa. Beberapa media yang dibuat secara sederhana oleh instruktur dengan biaya yang relatif murah sehingga dapat membantu pihak instruktur untuk mencoba dan mengaplikasikannya kepada pihak sasaran.

Kegiatan teaching yang dilaksanakan pada saat kegiatan Travelling and Teaching (TNT) \#18 menggunakan jenis media instruksional yang cukup bervariasi, diantaranya Wayang-wayangan, gambar/foto, puzzle, games (ular tangga, ludo dan monopoli), lagu, boneka-bonekaan dan peta. Surkarelawan mendapatkan referensi media instruksional ini dari internet seperti Google dan Youtube. Pembuatan media instruksional ini berdasarkan kreatifitas sukarelawan pengajar dengan menggunakan beberapa permainan seperti: ludo, monopoli, ular tangga, puzzle yang dipakai untuk pembelajaran dengan proses modifikasi sukarelawan pengajar yang ditambahkan sisipan materi atau bahan ajar yang ingin disampaikan atau yang sudah direncanakan sebelumnya.

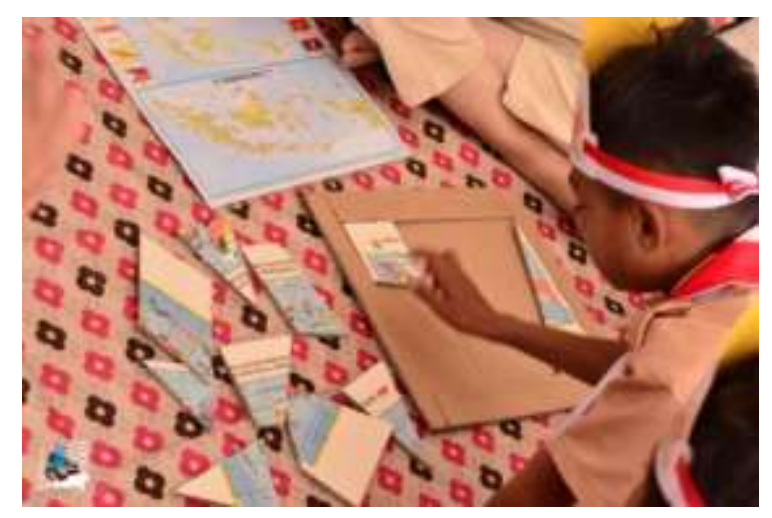

Gambar 2. Media Instruksional : Puzzle

Sumber: Dokumentasi 1000 Guru Bandung (2019)

Keempat, Organisasi Satuan-Satuan Instruksional. Variabel komunikasinya adalah pesan yang bergantung pada isi yang ingin disampaikan (dalam hal ini materi atau bahan ajar). Selaras dengan apa yang dikemukakan oleh Hurt, Scott dan Croscey dalam tahap ini informasi yang akan disampaikan dibagi ke dalam unit-unit kecil dengan sistematika yang berurutan. Mulai dari sederhana ke yang lebih rumit, maka dalam tahap ini juga sukarelawan pengajar melakukan beberapa aktivitas, diantaranya : 
1. Pembagian materi. Pada tahapan ini sukarelawan pengajar menentukan materi pembelajaran, alur dan teknis mengajar yang akan dilakukan dimulai dari yang mudah menuju yang rumit agar pelaksanaannya sesuai dengan waktu yang sudah disediakan oleh Tim Komunitas 1000 Guru Bandung;

2. Simulasi yang dilakukan dimulai dari pemaparan materi ataupun penggunaan media pembelajaran yang akan digunakan. Di dalam simulasi ini lah media pembelajaran diujicoba agar para sukarelawan pengajar yang berada di dalam satu kelas yang sama bisa saling memahami dan saling membantu apabila ada kendala atau kesulitan;

3. Menentukan alur pemaparan materi

4. Teknis penggunaan media instruksional yang digunakan permasing-masing sukarelawan pengajar. Hal ini dilakukan agar sukarelawan pengajar saling memahami dalam memberikan pemaparan materi dan saling membantu untuk menjelaskan jika ada pihak sasaran yang kurang mengerti atau ketika sukarelawan pengajar kesulitan menjelaskan materi yang ingin disampaikan.

5. Kelima, Umpan Balik. Jika dalam hal pembelajaran, umpan balik adalah penguasaan materi yang sudah direncanakan apakah sudah sesuai dengan tujuan instruksional yang direncanakan sebelumnya dan dapat diterima atau memiliki efek terhadap pihak sasaran seperti yang dikemukakan oleh Hurt, Scott dan Croscey dalam salah satu proses tahapan komunikasi instruksional. Maka Pada akhir pembelajaran, sukarelawan pengajar mengambil beberapa menit untuk melakukan review pada pelajaran atau materi yang sudah disampaikan sebelumnya kepada siswa Sekolah Dasar Negeri Cikidang karena review ini berguna untuk membangkitkan dan mengembangkan ide yang sudah sasaran punya sebelumnya. Tentu sukarelawan pengajar melakukan review yang umumnya dilakukan pada saat akhir pembelajaran saja, tapi adapun beberapa sukarelawan pengajar yang melakukan review pembelajaran di tengah-tengah pembelajaran ataupun di saat satu sisi materi pembelajaran berakhir.

Dalam tahap ini pula sukarelawan pengajar melakukan review sebagai alat untuk mengukur seberapa banyak siswa dapat menyerap dan paham terhadap pembelajaran yang sudah dilakukan sebelumnya. Review atau umpan balik yang dilakukan ialah dengan cara yang menarik serta kreatif di mana sukarelawan pengajar menggunakan cara games untuk me-review pembelajaran dengan media instruksional yang sebelumnya digunakan seperti puzzle, monopoli, ludo dan dijadikan kompetensi atau pertandingan sehingga siapa tim sasaran yang menang akan diberikan hadiah/reward. Adapun tanggapan yang diberikan 
oleh pihak sasaran ialah mereka lebih tertarik, senang, kontributif, tidak pasif, fokus, dan aktif selama proses pembelajaran berlangsung.

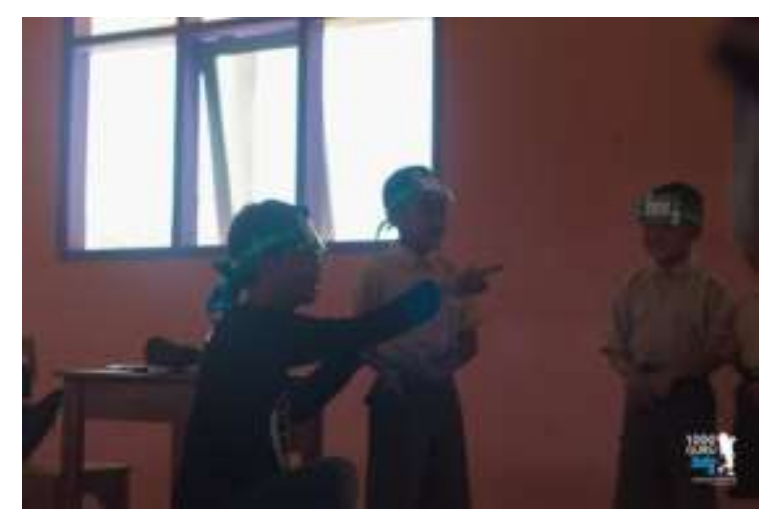

Gambar 3. Review pembelajaran melalui Games

Sumber: Dokumentasi 1000 Guru Bandung (2019)

Keenam, Evaluasi. Tahap ini tidak ada di dalam proses komunikasi instruksional yang dikemukakan oleh Hurt, Scott dan Croscey. Hanya saja evaluasi ini dilakukan pada saat kegiatan Travelling and Teaching (TNT) \#18 untuk mengetahui:

1. Hambatan apa saja yang terjadi pada saat proses pembelajaran berlangsung

2. Kekurangan dan kelebihan yang bisa dijadikan rujukan untuk acara Travelling and Teaching (TNT) selanjutnya (baik dari cara penyampaian materi ataupun media instruksional yang dipakai)

3. Materi atau bahan ajar yang disampaikan mudah untuk diberikan atau justru sulit

4. Mengukur kedekatan antara sukarelawan pengajar dengan siswa.

Terkait dengan hambatan-hambatan komunikasi instruksional yang terjadi selama di lapangan pada saat proses komunikasi instruksional berlangsung, dalam Yusup (2010) disebutkan bahwa hambatan dalam sistem instruksional terbagi menjadi 3 yakni hambatan pada sumber, hambatan pada saluran dan hambatan pada sasaran. Hambatan yang terjadi pada saat proses teaching di dalam kegiatan Travelling and Teaching (TNT) \#18 ialah tidak ada karena dari awal tujuan dan pembelajarannya sudah direncanakan secara matang sehingga pada proses pembelajarannya berlangsung hambatan-hambatan komunikasi instruksional baik itu hambatan dari sukarelawan pengajar, dari metode atau media yang digunakan maupun dari pihak siswa SDN Cikidang ini bisa dikurangi atau diminimalisir. Sukarelawan pengajar mengaku sudah on track dengan perencanaan yang dilakukan sebelumnya serta pembelajaran yang dilakukan sudah tepat sasaran.

Adapun kendala atau hambatan mengenai bahasa. Satu sukarelawan pengajar yang tidak bisa memakai bahasa Sunda selama pembelajaran berlangsung karena berasal dari 
luar kota Jawa Barat. Namun demikian hal itu tidak menjadi penghambat yang betul-betul menjadi penghalang dalam proses pembelajaran karena di setiap kelasnya sudah ada sukarelawan pengajar yang fasih berbahasa Sunda. Jika ada siswa yang ingin dijelaskan atau berbicara bahasa Sunda sukarelawan pengajar tersebut bisa menjadi penerjemah untuk sukarelawan pengajar yang lain. Di bawah ini adalah bagan dari proses komunikasi instruksional yang khas dilakukan oleh sukarelawan pengajar Komunitas 1000 Guru Bandung pada saat kegiatan Travelling and Teaching (TNT) \#18 di Sekolah Dasar Negeri Cikidang.

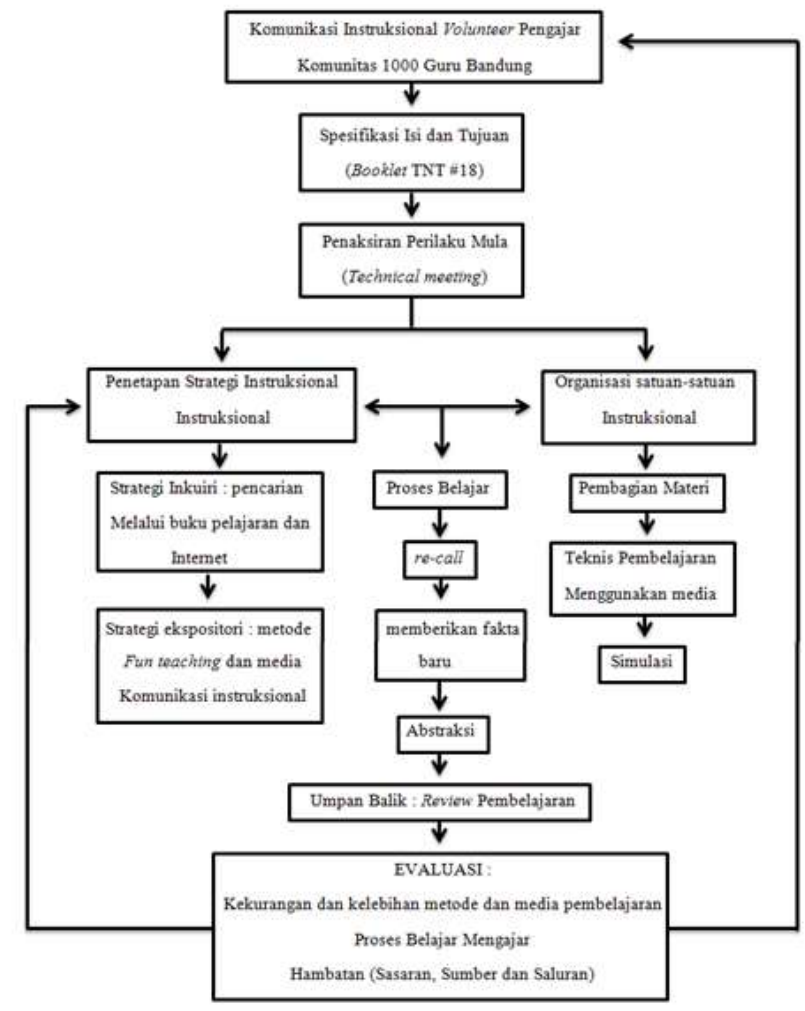

Gambar 4. Proses Komunikasi Instruksional Sukarelawan Pengajar Komunitas 1000 Guru Bandung Sumber: Pengolahan data oleh Peneliti (2019)

Berdasarkan hasil triangulasi mengenai proses sebuah komunikasi instruksional dari penelitian yang dilakukan oleh penulis pada kegiatan Travelling and Teaching (TNT) \#18 menunjukkan bahwa proses diawali dengan tahap persiapan yakni survei dan dilanjutkan dengan proses komunikasi instruksional yang khas. Hal tersebut dibenarkan oleh narasumber ahli. Survei di luar konteks proses komunikasi yang khas tetapi tetap tergabung ke dalam proses komunikasi instruksional karena dengan survei ini. Instruktur (sukarelawan pengajar) bisa mengetahui keadaan sasaran, sehingga proses komunikasi instruksional yang khas tetaplah dimulai dari tahap spesifikasi isi dan tujuan ketika sukarelawan pengajar sudah berhadapan langsung dengan sasaran (Siswa Sekolah Dasar Negeri Cikidang). Hal ini yang juga dibenarkan oleh narasumber ahli yakni Pawit M. 
Yusup bahwa penetapan spesifikasi isi dan tujuan yang sesuai dengan kompetensi dasar awal sasaran agar setara tidak terlalu tinggi ataupun rendah yaitu Komunitas 1000 Guru Bandung menetapkan tujuan instruksional berdasarkan referensi dari kurikulum sekolah.

Narasumber ahli mengatakan bahwa umpan balik tidak selamanya berbentuk review saja melainkan bisa saja berbentuk tanya jawab, ringkasan materi dan sasaran menampilkan hasil karya nya tetapi hasil penelitian menunjukkan bahwa sukarelawan pengajar hanya melakukan review dan sasaran memberikan tanggapan. Hasil penelitian juga menunjukkan tidak adanya hambatan di dalam kegiatan Travelling and Teaching (TNT) \#18 ini karena tujuan pembelajarannya sudah direncanakan secara matang sebelumnya. Hal ini disetujui oleh narasumber ahli yang menyatakan bahwa hambatan dalam komunikasi instruksional bisa dieliminir atau bisa dihindari karena proses komunikasi instruksional ini sudah direncanakan sedemikian rupa, meskipun hambatan tidak menjadi formal di dalam proses komunikasi instruksional tetapi hambatan ini tetap menjadi bagian atau komponen dari sebuah proses komunikasi instruksional.

Penelitian ini sejalan dengan penelitian terdahulu yang dilakukan oleh Andri Yanto, bahwa seluruh aktivitas literasi yang ada pada kegiatan Travelling and Teaching (TNT) \#18 sangat bergantung pada sukarelawan pengajar dalam proses perencanaan dan persiapan berbagai program yang menjadi aktivitas literasi TNT \#18. Evaluasi sangat penting dan perlu dilakukan secara rutin pada seluruh aktivitas literasi TNT \#18. Hal ini dilakukan untuk mengetahui berbagai hambatan yang terjadi, serta kelebihan dan kekurangan yang dapat dijadikan rujukan pada kegiatan Travelling and Teaching (TNT) \#18 lainnya.

\section{SIMPULAN}

Berdasarkan hasil penelitian, maka penulis dapat memperoleh kesimpulan bahwa proses komunikasi instruksional yang dilakukan oleh sukarelawan pengajar Komunitas 1000 Guru Bandung dimulai dari spesifikasi isi dan tujuan instruksional mengenai materi dan aktivitas pembelajaran yang ada di dalam booklet TNT \#18. Tahap selanjutnya adalah penaksiran perilaku mula di dalam kegiatan technical meeting untuk menginformasikan mengenai kemampuan siswa. Tahap ketiga berupa penetapan strategi instruksional. Langkah berikutnya adalah organisasi satuan-satuan instruksional. Tahap terakhir adalah umpan balik dengan cara review pembelajaran.

Komponen atau proses tambahan pada proses komunikasi instruksional di akhir sesudah melakukan review ialah evaluasi mengenai proses komunikasi instruksional secara keseluruhan dan juga hambatan, tetapi hambatan ini bisa dieliminir atau bisa dihindari karena proses komunikasi instruksional ini sudah direncanakan sedemikian rupa 
sebelumnya. Penelitian ini hanya berfokus pada aktivitas literasi TNT \#18. Untuk itu pada penelitian selanjutnya, diharapkan untuk melakukan penelitian lebih mendalam mengenai sukarelawan pengajar Komunitas 1000 Guru Bandung. Melalui penelitian lanjutan tersebut, diharapkan dapat terciptanya inovasi dalam berbagai kegiatan sukarelawan pengajar Komunitas 1000 Guru Bandung demi mewujudkan sistem pembelajaran yang lebih baik lagi.

\section{Kontribusi Pada Keilmuan}

Penelitian ini merupakan Kajian di dalam bidang Komunikasi Instruksional. Penelitian ini juga berkaitan dengan bidang atau keilmuan komunikasi instruksional dan lebih menekankan pada proses komunikasi instruksional yang dilakukan oleh sukarelawan pengajar Komunitas 1000 Guru Bandung kepada anak-anak Sekolah Dasar pada saat kegiatan Travelling and Teaching (TNT). Hasil penelitian ini dapat menjadi dasar untuk penelitian selanjutnya atau penelitian bidang sejenis mengenai Komunikasi Instruksional serta dapat menjadi sumber inspirasi bagi penelitian di bidang terkait komunikasi instruksional.

\section{Pernyataan Minat Kajian}

Peneliti bernama Annisa Yuniar memiliki minat kajian dalam bidang Komunikasi Instruksional. Peneliti bernama Rohanda memiliki minat kajian dalam bidang Manajemen Lembaga Perpustakaan, Dokumentasi dan Informasi, Informasi Publik, dan Bibliometrika. Peneliti Fitri Perdana memiliki minat kajian dalam bidang Museum, Perpustakaan Sekolah, dan Pemasaran Informasi.

\section{Kontribusi Peneliti}

Peneliti melakukan observasi dan wawancara, mengumpulkan data dengan cara dokumentasi, studi pustaka dan analisis data.

\section{DAFTAR PUSTAKA}

Badan Pengembangan dan Pembinaan Bahasa (Pusat Bahasa). (2020). Kamus besar bahasa indonesia (KBBI). Retrieved from https://kbbi.kemdikbud.go.id/entri/sukarelawan

Moleong, L. J. (2012). Metode penelitian kualitatif(Revisi). Bandung: Remaja Rosdakarya.

Muhaimin, M. (2011). Upaya peningkatan hasil belajar aqidah akhlak pada materi membiasakan akhlak terpuji melalui metode sosiodrama pada siswa kelas V di MI An Nur Deyangan kecamatan Mertoyudan kabupaten Magelang (Skripsi). Institut Agama Islam Negeri Walisongo, Semarang. Retrieved from http://eprints.walisongo.ac.id/2375/

Rizkiawati, R. (2017). Pentingnya buku panduan bagi volunteer pada organisasi sosial: studi kasus pada Lembaga Rehabilitasi ODHA dan konsumen NAPZA Rumah Cemara Kota Bandung. Share Social Work Journal, 7:2, 53-61. Retrieved from http://jurnal.unpad.ac.id/share/article/view/15723

Sugiyono. (2008). Metode penelitian kuantitatif, kualitatif, dan R\&D. Bandung: Alfabeta. Yusup, P. M. (2010). Komunikasi instruksional : teori dan praktik. Jakarta: Bumi Aksara 